\title{
Transformation of the Diatom Phaeodactylum tricornutum with its Endogenous (E)-4-Hydroxy-3-methylbut-2-enyl Diphosphate Reductase Gene
}

\author{
Bok-Kyu Shin (D) ' Yu-Jin Jung (D) - Sang-Min Kim* (D) C Cheol-Ho Pan* (D)
}

\section{Phaeodactylum tricornutum 의 (E)-4-Hydroxy-3-methylbut-2-enyl Diphosphate Reductase 유전자의 형질전환}

\author{
신복규 · 정유진 · 김상민* · 판철호*
}

Received: 22 July 2015 / Accepted: 28 July 2015 / Published Online: 30 September 2015

(C) The Korean Society for Applied Biological Chemistry 2015

\begin{abstract}
Phaeodactylum tricornutum is a model diatom that its genomic information and biological tools are well established. In this study, a gene encoding (E)-4-hydroxy-3-methylbut-2-enyl diphosphate reductase (PtHDR), a terminal enzyme of the methylerythritol phosphate pathway regulating chlorophyll and carotenoid biosynthesis, was isolated from $P$. tricornutum. The isolated gene was cloned into pPha-T1 vector containing $f c p A$ promoter to prepare pPha-T1-HDR plasmid. As a positive control, pPha-T1-eGFP plasmid was constructed with egfp gene. Stable nuclear transformation was carried out with these plasmids by particle bombardment method and zeocin resistant colonies of $P$. tricornutum were selected on $\mathrm{f} / 2$ agar plate. In result, transformation efficiency was evaluated according to the amount of plasmid DNA coated with gold particles. Integration of introduced plasmids was confirmed with genomic DNA of each transformant by polymerase chain reaction. The eGFP fluorescence was visible in the cytoplasm, indicating that eGFP was successively expressed in P. tricornutum system. The transcript level of exogenous Pthdr
\end{abstract}

\section{B.-K. Shin · Y.-J. Jung · S.-M. Kim · C.-H. Pan}

Laboratory of Biomodulation, Natural Products Research Center, KIST Gangneung Institute of Natural Products, Gangneung, Gangwon-do 210340, Republic of Korea

\section{*Corresponding authors}

(C.-H. Pan: cheolpan@gmail.com; S.-M. Kim:kimsm@kist.re.kr)

This is an Open Access article distributed under the terms of the Creative Commons Attribution Non-Commercial License (http://creativecommons. org/licenses/by-nc/3.0/) which permits unrestricted non-commercial use, distribution, and reproduction in any medium, provided the original work is properly cited. gene was evaluated with the obtained transformants. The results presented here demonstrated that introduction of Pthdr gene into P. tricornutum chromosome succeeded and expression of PtHDR was enhanced under the $f c p A$ promoter.

Keywords bombardment - (E)-4-hydroxy-3-methylbut-2-enyl diphosphate reductase $\cdot$ Phaeodactylum tricornutum . transformation

서 론

규조류(Diatom)는 풍부하고 다양한 광합성 미세조류로 해수 및 담수 모두에서 발견된다(Werner, 1977; Round 등, 1990). 이런 규조류는 지구생물화학적 순환에서 중요한 역할을 하며, 지구 일차대사산물의 20\%를 생산한다(Falkowski 등, 1998; Field 등, 1998; Kroth, 2007). 규조류는 크게 두 분류, 즉 pennates와 centrics로 나누어 진다. Phaeodactylum tricornutum Bohlin은 pennates에 속하는 규조류로 환경적 자극에 의해 방추형 (fusiform), 삼각방추형(triadiate), 타원형(oval), 십자형(cruciform) 등의 형태로 존재할 수 있다(Martino 등, 2007; He 등, 2014). 또한 P. tricorntum은 다른 규조류와 다르게 약하게 규화된 세 포벽을 가지고 있다(Martino 등, 2007; Francius 등, 2008). $P$. tricornutum 은 유용 물질인 불포화 지방산 및 카로티노이드 화 합물인 fucoxanthin을 다량 함유하고 있는 것으로 알려져 있다 (Owens, 1986; Patil, 2005). Fucoxnathin의 경우 항암효과 (Talero 등, 2012), 라디칼 소거능(Nomura 등, 1997), 그리고 항비만 효과 등이 보고된 차세대 고부가가치 화합물로 여겨지 
고 있는 소재이다(Maeda 등, 2005; Matsumoto 등, 2010). 규 조류 중 게놈 서열이 완성된 두 종이 있는데, 그 중에 한 종이 P. tricornutum 이고(Bowler 등, 2008), 또한 130,000 여종이 넘 는 EST가 밝혀져 있어, P. tricornutum은 규조류 연구에 있어 모델 종으로 여겨지고 있다(Maheswari 등, 2005; Maheswari 등, 2009). 또한 bombardment 및 electroporation 방법에 의한 형질전환 방법이 개발되어 있어 여러 가지 분자생물학적 기술 을 적용할 수 있다(Apt 등, 1996; Siaut 등, 2007; De Riso 등, 2009).

(E)-4-hydroxy-3-methylbut-2-enyl diphosphate reductase (HDR) 은 methylerythritol phosphate (MEP) 경로의 마지막 효소로 (E)-4-hydroxy-3-methylbut-2-enyl diphosphate (HMBPP)를 환원 시켜 isopentenyl diphosphate (IPP)와 dimethylallyl diphosphate (DMAPP)로 만드는 과정에 관여한다(Fig. 1). IPP와 DMAPP는 테르페노이드 계열 화합물의 전구체로 사용되며 IPP와 DMAPP 비율에 따라 geranyl diphosphate (GPP, IPP:DMAPP=1:1), farnesyl diphsophat (FPP, IPP:DMAPP=2:1), 그리고 geranylgeranyl diphosphate (GGPP, IPP:DMAPP=3:1)가 형성된다. 이렇게 형 성된 $\mathrm{FPP}, \mathrm{GPP}$ 와 GGPP는 카로티노이드, 테프펜류 화합물, 클 로로필 등의 생합성에 쓰이게 된다. 따라서 $\mathrm{HDR}$ 은 생합성 과 정 중, IPP와 DMAPP 비율을 결정하는 첫 단계의 중요한 효 소라 할 수 있다. HDR의 연구는 대부분 Escherichia coli를 비 롯한 세균 유래의 HDR에 대해 진행되었고(Altincicek 등, 2002; Rohdich 등, 2002; Wolff 등, 2003; Gräwert 등, 2004), 일부 고등식물 유래의 $\mathrm{HDR}$ 에 대한 연구도 진행되어 왔다(Kim 등, 2008; Kang 등, 2013; Shin 등, 2015). 그러나 아직 미세 조류 유래의 $\mathrm{HDR}$ 에 대한 연구는 거의 진행되지 않았다.

미세조류는 엽록체에 $\mathrm{MEP}$ 대사경로가 존재하고, 이들이 광 합성에 관련된 클로로필이나 카로티노이드의 생합성에 관여한 다고 추측되고 있다(Lohr 등, 2012). 그러므로 미세조류는 HDR 을 통한 IPP:DMAPP의 비율이 최종 산물, 특히 카로티노이드 에 어떻게 영향을 주는지에 대한 연구에서 좋은 소재가 된다. 특히 규조류인 P. tricornutum은 fucoxanthin이라는 유용한 최종 산물을 다량 함유하고 있고 그 생합성 기작이 명확하지 않기 때문에 연구의 가치가 높으며, 게놈 염기서열이 밝혀진 점 및 형질전환 방법이 개발된 점 때문에 이러한 연구 목적에 알맞다 (Apt 등, 1996; Siaut 등, 2007; Bowler 등, 2008; De Riso 등, 2009). 본 연구에서는 미세조류에서 HDR 단백질 발현 증 대와 카로티노이드 등의 최종 대사산물과의 상관관계를 연구하 기 위한 첫 단계로 P. tricornutum의 $\mathrm{HDR}$ 단백질 과발현 형질 전환체를 확보하는 것을 진행하였다.

\section{재료 및 방법}

배양. P. tricornutum Bohlin은 UTEX The Culture Collection of Algae at The University of Texas at Austin (UTEX646) 으로부터 분양 받아 사용하였다. 배양에는 $\mathrm{f} / 2$ 배지를 사용하였 고(Guillard and Ryther, 1962; Guillard, 1975), $20^{\circ} \mathrm{C}$ 에서 통기 (aeration)배양하였다. 해수는 $50 \%$ 인공해수를 고압멸균 후 사 용하였다. 배양 시 박테리아 오염을 제거하기 위해 ampicillin $(50 \mu \mathrm{g} / \mathrm{mL})$, kanamycin $(10 \mu \mathrm{g} / \mathrm{mL})$, 그리고 streptomycin $(50$ $\mu \mathrm{g} / \mathrm{mL}$ )을 첨가하였다. 형질전환을 위한 배양에는 $\mathrm{f} / 2$ 배지 성분 중 $\mathrm{Na}_{2} \mathrm{SiO}_{3}$ 를 제외한 배지 $\mathrm{f} / 2-\mathrm{Si}$ 를 사용하였다.

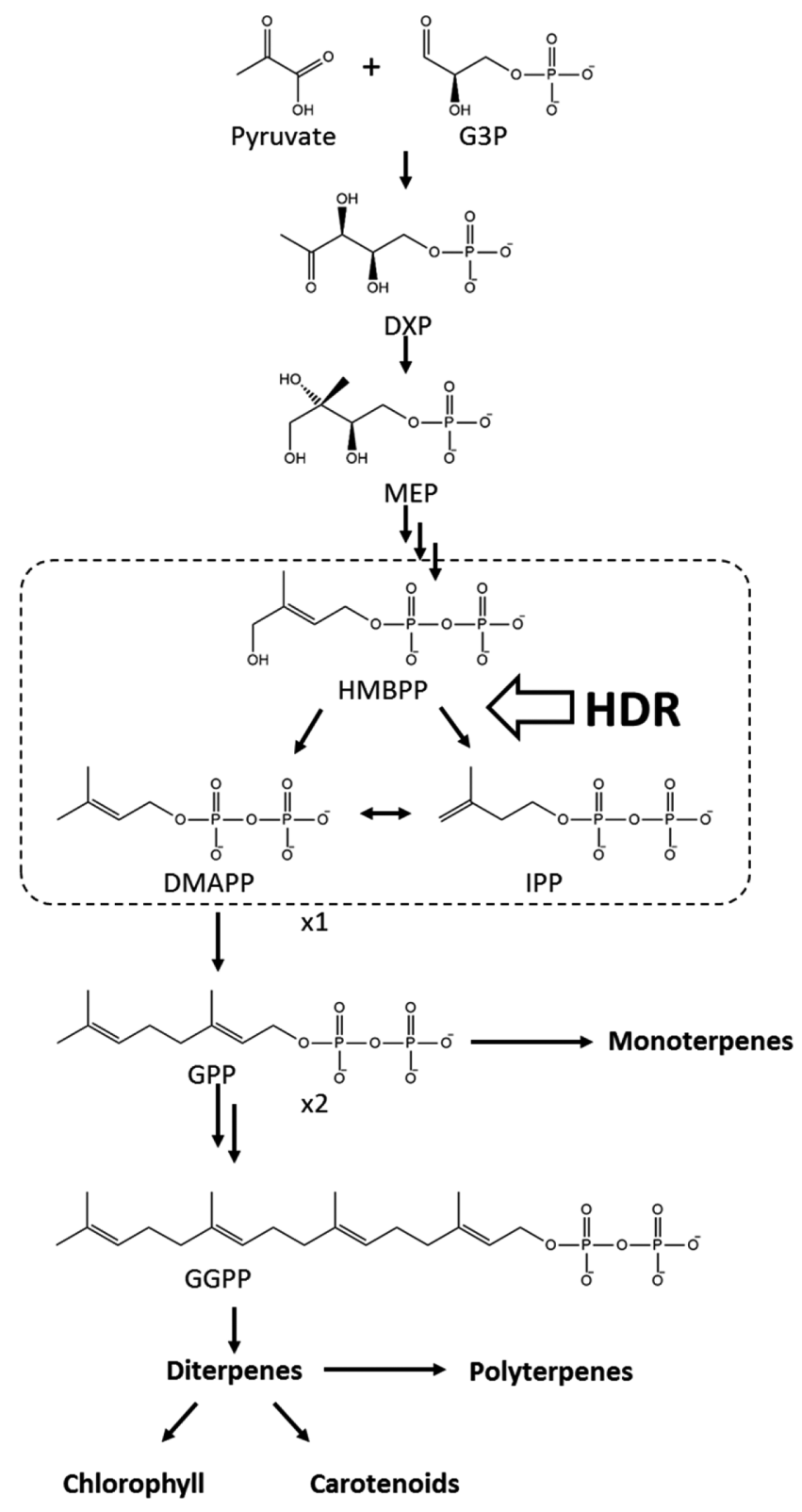

Fig. 1 MEP pathway in a chloroplast of Diatom. HDR; $(E)-4$-hydroxy-3methylbut-2-enyl diphosphate reductase, G3P; glyceraldehyde-3-phopshate, DXP; 1-deoxyxylulose-5-phosphate, MEP; $2 C$-methyl-D-erythritol-4phosphate, HMBPP; (E)-4-hydroxy-3-methylbut-2-enyl diphosphate, DMAPP; dimethylallyl diphosphate, IPP; isopentenyl diphosphate, GPP; geranyl diphosphate, GGPP; geranylgeranyl diphosphate.

유전자 클로닝. P. tricornutum의 $\mathrm{HDR}$ 효소에 대한 유전자 정 보는 'The Diatom EST Database (http://www.diatomics.biologie. ens.fr/EST3/index.php)' 및 'DiatomCyc: Encyclopedia of Diatom Genes and Metabolism (http://www.diatomcyc.org/)'으로부터 확 보하였다(EST data; G41845, DiatomCyc; PHATRDRAFT_ 50808). P. tricornutum의 형질전환에 사용할 pPha-T1 vector 는 Peter Kroth 박사로부터 분양받았다(Zaslavskaia 등, 2000). P. tricornutum으로부터 $h d r$ 유전자 $(P t h d r)$ 를 분리하기 위한 $\mathrm{cDNA}$ 는 다음과 같이 준비하였다. 정지기(stationary phase)까지 
키운 P. tricornutum 배양액 $50 \mathrm{~mL}$ 를 $3,500 \mathrm{rpm}$ 에서 15 분간 원 심분리하여 세포를 모은 후 액체 질소에 얼려 분쇄한 후 RNeasy ${ }^{\circledR}$ Plant Mini Kit (QIAGEN, Netherlands)를 사용하여 mRNA를 추출하였다. 이 후 QuantiTect ${ }^{\circledR}$ Reverse Transcription Kit (QIAGEN)의 프로토콜에 따라 $\mathrm{cDNA}$ 를 합성하였다. Pthdr 유전자는 PtHDR-F/-R 프라이머를 사용하여 cDNA로부터 polymerase chain reaction (PCR)을 통하여 증폭되었고, EcoRI와 $\mathrm{BamHI}$ 제한효소 처리 후 pPha-T1 벡터에 ligation 되었다. 이 후 E. coli $(\mathrm{DH} 5 \mathrm{a})$ 에 형질전환 된 후 ampicillin $(50 \mu \mathrm{g} / \mathrm{mL})$ 이 포함된 LB 배지에서 스크리닝되어 최종적으로 pPha-T1$\mathrm{HDR}$ 플라스미드를 확보하였다. 양성대조군으로 사용할 Enhanced green fluorescence protein (egfp) 유전자는 pEGFP$\mathrm{C} 2$ 벡터로부터 $\mathrm{PCR}$ 을 통하여 분리되었고, 위와 같은 방법으로 $\mathrm{pPha}-\mathrm{T} 1$ 벡터에 클로닝되어 최종적으로 $\mathrm{pPha}-\mathrm{T} 1-\mathrm{eGFP}$ 플라스 미드를 확보하였다. 각 플라스미드가 포함된 E. coli는 $200 \mathrm{~mL}$ LB배지(amplicilin $50 \mu \mathrm{g} / \mathrm{mL}$ 포함)에서 배양 후, HiSpeed ${ }^{\circledR}$ Plasmid Midi Kit (QIAGEN)로 플라스미드를 회수한 후, phenol/chloroform 방법으로 정제하여 최종 농도가 $1.0 \mu \mathrm{g} / \mathrm{mL}$ 이 되도록 제조하여 P. tricornutum 형진전환에 사용하였다.

Particle Bombardment. 정지기까지 키운 $1.5 \times 10^{7}$ cells $/ \mathrm{mL}$ 농 도의 P. tricornutum 배양액 $35 \mathrm{~mL}$ 를 $3,500 \mathrm{rpm}$ 에서 15 분간 원 심분리하여 미세조류 세포를 회수한 후, $200 \mu \mathrm{L}$ 의 $50 \%$ 멸균 해 수로 다시 현탁 시켜 $1.5 \% \mathrm{f} / 2$ 한천배지 중심에 직경이 $5 \mathrm{~cm}$ 이내가 되도록 도말하였다. $\mathrm{f} / 2$ 한천배지에 도말한 $P$. tricornutum을 $20^{\circ} \mathrm{C}, 5,000 \mathrm{LUX}$ 형광등 빛에서 24시간 동안 배양한 후, bombardment를 통한 형질전환에 사용하였다. 형질 전환에는 pPha-T1-HDR, pPha-T1-eGFP 플라스미드와 음성 대 조군으로 $\mathrm{pPha}-\mathrm{T} 1$ 벡터를 사용하였다(Table 1). 형질전환은 Biolistic $^{\circledR}$ PDS-1000/He Particle Delivery System (BIO-RAD, USA)을 사용하였다. Gold microcarrier (직경 $1 \mu \mathrm{m}$ )는 $70 \%$ 에 탄올에 소독하고 멸균수로 세척 후, $50 \%$ 글리세롤 용액에 현 탁하여 $60 \mathrm{mg} / \mathrm{mL}$ 농도로 만든 후, 사용 전까지 $4^{\circ} \mathrm{C}$ 냉장고에 보관하였다. 각 플라스미드 $1-4 \mu \mathrm{L}(1 \mu \mathrm{g} / \mathrm{mL})$ 와 $2.5 \mathrm{M} \mathrm{CaCl}_{2}$ $10 \mu \mathrm{L}, 0.1 \mathrm{M}$ spermidine $2 \mu \mathrm{L}$ 를 gold microcarrier에 각각 섞 어 코팅하였다. DNA가 코팅 된 gold microcarrier는 $70,100 \%$ 에탄올 순으로 씻은 후에 $100 \%$ 에탄올에 현탁하여 사용하였다. 유전자도입은 $1,350 \mathrm{psi}$ 에서 발사 지점부터 형질전환 대상 세포 간의 거리 $6 \mathrm{~cm}$ 에서 실시하였다.

유전자 도입 후, P. tricornutum은 $\mathrm{f} / 2$ 한천배지에서 그대로
1-3일 동안 5,000 LUX 형광등 빛, $18^{\circ} \mathrm{C}$ 에서 회복을 위한 배 양을 하였다. 이후 $\mathrm{f} / 2$ 한천배지 위의 P. tricornutum을 회수하 여 $\mathrm{f} / 2$ 액체배지 $500 \mu \mathrm{L}$ 에 현탁하였다. 이 현탁액을 항생제 zeocin이 $100 \mu \mathrm{g} / \mathrm{mL}$ 농도로 포함된 $1.5 \% \mathrm{f} / 2$ 한천배지 4 개에 나누어 도말하였다. 형질전환체는 10 일에서 4 주 내에 육안으로 확인할 수 있었다. 형질전환 콜로니는 $100 \mu \mathrm{g} / \mathrm{mL}$ zeocin이 첨 가된 $\mathrm{f} / 2$ 액체 배지에 $200 \mu \mathrm{L}, 2.0 \mathrm{~mL}, 20 \mathrm{~mL}$ 그리고 $200 \mathrm{~mL}$ 순으로 $20^{\circ} \mathrm{C}, 5,000 \mathrm{LUX}$ 형광등 빛에서 교반 배양하였다.

Genomic DNA-PCR. 확보한 P. tricornutum의 형질전환체로부 터 유전자 도입을 통해 크로모좀(chromosome)에 각 플라스미 드가 안정적으로 도입되었는지를 genomic DNA-PCR을 통하여 확인하였다. P. tricornutum 형질전환체 배양액 $50 \mathrm{~mL}$ 를 취하여 원심분리 (3,500 rpm, 15 분) 를 통해 세포를 모은 후, 액체 질 소에 얼려서 분쇄한 후, DNeasy ${ }^{\circledR}$ Plant Mini Kit (QIAGEN) 로 genomic DNA를 추출하였다. 추출한 genomic DNA를 사용 하여 PCR을 수행하였다. P. tricornutum의 게놈에 Pthdr 유전자 가 이미 존재하기 때문에 pPha-T1-HDR 플라스미드의 형질전 환 유무에는 PtHDR-F 프라이머와 pPha-T1 벡터의 multi cloning 지역에 위치한 pPha-T1-R 프라이머를 사용하였다(Table 1). egfp 유전자의 경우는 eGFP-F/-R 프라이머를 사용하였고, pPha$\mathrm{T} 1$ 벡터 형질전환체의 확인에는 zeocin 항생제 유전자를 검출 하기 위해 Shble-F/-R 프라이머를 사용하였다. PCR은 Taq polymerase를 사용하였으며, $95^{\circ} \mathrm{C}$ 에서 30 초, $60^{\circ} \mathrm{C}$ 에서 30 초, 그 리고 $72^{\circ} \mathrm{C}$ 에서 2 분 주기로 35 회 순환 시켰다.

Reverse-Transcription PCR. 정지기까지 키운 $1.5 \times 10^{7}$ cells/ $\mathrm{mL}$ 농도의 P. tricornutum 배양액 $50 \mathrm{~mL}$ 를 $3,500 \mathrm{rpm}$ 에서 15 분간 원심분리하여 미세조류 세포를 회수한 후, 액체 질소에 얼 려서 갈고, 앞서 기술한 바와 같이 RNA를 추출하고, $\mathrm{cDNA}$ 를 합성하였다. Genomic DNA에 도입된 각 플라스미드에서 각 유 전자의 전사체(transcript)가 만들어지는지 확인하기 위하여 PCR 을 수행하였다. Pthdr 유전자의 경우는 endogenous Pthdr 전사 체와 도입된 플라스미드 유래 $P t h d r$ 전사체를 구별하기 위해 PtHDR-F/pPha-T1-R 프라이머 조합을 사용하였고, 전체 Pthdr 전사체를 검출하기 위해 $\mathrm{PtHDR}-\mathrm{F} / \mathrm{-R}$ 프라이머를 사용하였다 (Table 1). egfp 유전자의 경우는 eGFP-F/-R 프라이머를 사용하 였다.

Confocal Microscopy. egfp 유전자가 도입된 P. tricornutum 형질전환체 내의 eGFP 발현 여부는 공초점 현미경을 통해 확 인하였다. 공초점 현미경은 서울대학교 농생명과학공동기기원의

Table 1 List of vectors and primers for this study

\begin{tabular}{|c|c|c|c|}
\hline \multirow{2}{*}{ Vector } & \multicolumn{2}{|r|}{ Primer } & \multirow{2}{*}{$\begin{array}{c}\text { Restriction } \\
\text { enzyme }\end{array}$} \\
\hline & Name & Sequence & \\
\hline \multirow{4}{*}{ pPha-T1-HDR } & PtHDR-F & ATGAAGTCCGATCGCTTCCATC & - \\
\hline & PtHDR-R & CTATTTCTTGCTCTCGTCGTAC & - \\
\hline & PtHDR-RE-F & ATCGAGAATTCATGAAGTCCGATCGCTTCCATC & EcoRI \\
\hline & PtHDR-RE-R & ATCGGATCCCTATTTCTTGCTCTCGTCGTAC & BamHI \\
\hline \multirow{2}{*}{ pPha-T1-eGFP } & eGFP-F & CGCGAATTCATGGTGAGCAAGGGC & EcoRI \\
\hline & eGFP-R & CGCGAATTCTTACTTGTACAGCTCGTCCAT & EcoRI \\
\hline \multirow{4}{*}{ pPha-T1 } & pPha-T1-F & GCAAGATCAGCTGGCCTAGCAAGAG & - \\
\hline & pPha-T1-R & ACTCCCAACTGTTCGTGCACCATG & - \\
\hline & Shble-F & ATGGCCAAGTTGACCAGTGC & - \\
\hline & Shble-R & TCAGTCCTGCTCCTCGGC & - \\
\hline
\end{tabular}


SP8XSTED (Leica)를 사용하였다. eGFP 단백질의 형광 발현을 확인하기 위해, excitation 파장은 $488 \mathrm{~nm}$ 로 하였고, $507 \mathrm{~nm}$ 에 서 형광파장을 측정하였다.

\section{결과 및 고찰}

Pthdr 유전자 정보 및 클로닝. The Diatom EST Database 및 DiatomCyc: Encyclopedia of Diatom Genes and Metabolism 에서 Pthdr 유전자의 염기 서열을 확인하였다. 현재까지 알려진 정보에 의하면 P. tricorntum은 한 종류의 $h d r$ 유전자를 가지는 것으로 추정된다. 이는 고등식물과는 배치되는 부분으로, 식물 에서는 두 개 이상의 $h d r$ 유전자가 존재 하는 것으로 알려져 있다. 은행나무(Ginkgo biloba) 및 테다소나무(Pinus taeda)의 경우 각각 3 (GbHDR1, GbHDR2 그리고 GbHDR2-1)및 2 개 (PtHDR1 및 PtHDR2) 의 $h d r$ 유전자가 확인 되었다(Kim 등, 2008). 이 논문에 의하면, 은행나무의 GbHDR1은 주로 빛이 있 을 때 잎에서 발현이 증가하고, GbHDR2 는 methyl jasmonate 처리 시 뿌리에서 발현이 증가한다. 이를 통해 GbHDR1은 1차 대사에, GbHDR2는 2차 대사에 관련 있다고 추측하였다.

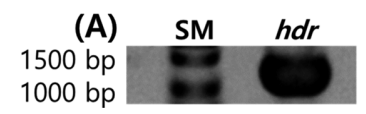

(B) SM egfp $750 \mathrm{bp} \longrightarrow$

Fig. 2 Gene extraction of a Pthdr gene (A) and an egfp gene (B) from a $P$. tricornutum cDNA and a pEGFP-C2 vector, respectively. SM; size marker.

본 실험에 사용한 Pthdr 유전자는 P. tricornutum (UTEX 646)의 cDNA 로부터 PCR (PtHDR-F/-R) 을 통해 증폭하였고, egfp 유전자는 pEGFP-C2 벡터로부터 eGFP-F/-R primer를 사 용하여 PCR로 증폭하였다(Fig. 2). 증폭한 Pthdr 및 egfp 유전 자는 제한효소 처리 후 pPha-T1 벡터에 클로닝 하였다.

PtHDR 효소의 1차 구조를 분석하기 위하여 다른 미세조류 및 식물, 박테리아 유래 HDR 효소의 아미노산 서열과 비교해 보았다(Fig. 3). $\mathrm{HDR}$ 에서는 활성자리의 $\mathrm{Fe} / \mathrm{S}$ 클러스터를 잡는 3 개의 Cys 잔기 $(\mathrm{C} 114,206,337)$, 기질 결합과 관련이 있는 2 개의 $\mathrm{His}$ 잔기 $(\mathrm{H} 144,234)$ 및 1개의 $\mathrm{Ser}(\mathrm{S} 370)$, 1개의 Asn (N372), 그리고 수소전달과 관련 1개의 Glu (E236)와 1개의 $\mathrm{Thr}$ (T299) 등, 총 9개의 염기서열이 공통 염기 서열로 알려져 있다(Gräwert 등, 2004; Gräwert 등, 2009; Gräwert 등, 2010;

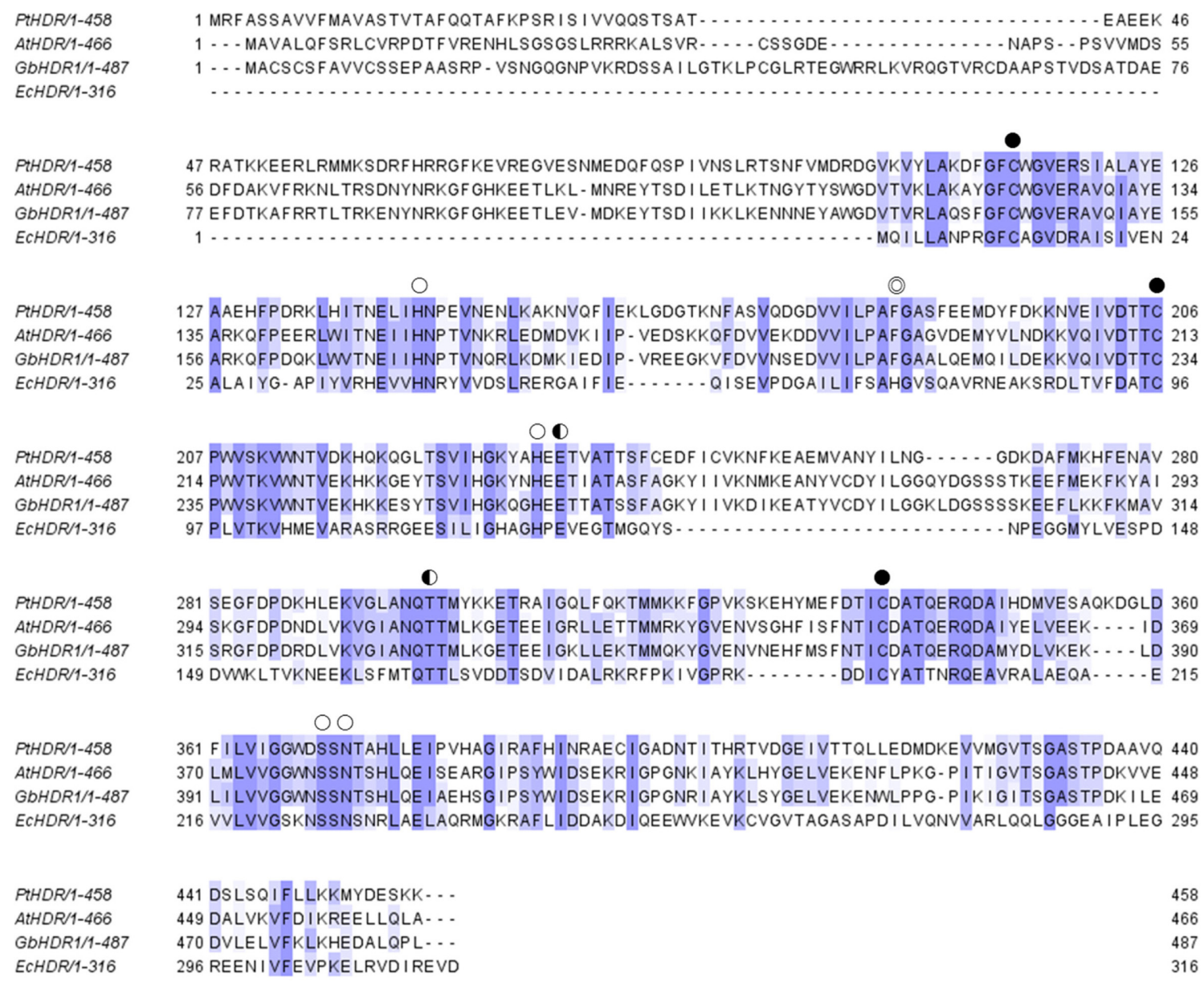

Fig. 3 Alignment of amino acid sequences of HDR proteins. Consensus cysteins ( $\bigcirc$ ), consensus histidines, serine and arginine ( $\bigcirc$ ), consensus phenylalanine ( ( ) ), and consensus glutamic acid and threonine (O) were marked by each symbols. Pt; Phaeodactylum tricornutum, At; Arabidopsis thaliana, Gb; Ginkgo biloba, Ec; Escherichia coli. 
Span 등, 2012). PtHDR도 다른 HDR과 마찬가지로 9개의 공 통 염기서열을 가지고 있는 것으로 보인다. 또한 고등식물 $\mathrm{HDR}$ 과 마찬가지로 활성자리 주변에 1개의 Phe (F184)을 가지고 있 다. 박테리아의 경우 같은 위치에 $\mathrm{His}$ 잔기를 가지고 있어, 식 물의 HDR과 구별된다(Shin 등, 2015).

형질전환을 위한 P. tricornutum 배양. 사전 연구에 의하면, $P$. tricornutum은 다른 규조류에 비해 규소가 결핍된 상태에서도 잘 자라는 것으로 알려져 있다(Lewin 등, 1958; Borowitzka and Volcani, 1978). 또한 규소가 결핍된 배지에서 배양하면 규 소 기반의 세포벽 생성을 최소화하여 bombardment시 형질전환 효율이 증가한다는 보고가 있다(Niu 등, 2012). 따라서 형질전 환을 위한 P. tricornutum 의 배양에서는 $\mathrm{f} / 2$ 에서 규소 성분을 제 외한 $\mathrm{f} / 2-\mathrm{Si}$ 배지를 사용하였다. 형질전환 이후 선별과정에서, $100 \%$ 해수를 사용할 때보다 $50 \%$ 해수를 사용할 경우 zeocin 항생제에 대한 민감도가 증가하는 것으로 알려져 있다(Falciatore 등, 1999). 기존의 논문을 따른 본 연구그룹의 사전연구에서도 $100 \%$ 해수를 사용한 배지에서 배양할 경우, P. tricornutum 농 도가 $1.0 \times 10^{6}$ cells $/ \mathrm{mL}$ 이면 $100 \mu \mathrm{g} / \mathrm{mL}$ zeocin이 첨가된 배지에 서 일부가 자라지만, $50 \%$ 해수를 사용한 배지에서는 자라지 못 하였다(data not shown). 이 결과를 토대로 본 연구에서도 형질 전환체 선별을 위해 $50 \%$ 인공해수를 사용하여 $100 \mu \mathrm{g} / \mathrm{mL}$ 농 도의 zeocin이 함유된 $\mathrm{f} / 2$ 배지를 사용하였다.

Bombardment를 이용한 형질전환. Bombardment 형질전환 조 건은 기존에 보고된 조건을 참고하여 효율이 좋은 조건으로 진 행하였다(Apt 등, 1996; Falciatore 등, 1999). Microcarrier는 직경 $1 \mu \mathrm{m}$ gold 입자에 $1 \mu \mathrm{g}$ 의 목적 유전자가 포함된 플라스 미드를 코팅하여 사용하고, 유전자 발사 시점으로부터 $P$. tricornutum까지의 거리는 $6 \mathrm{~cm}$, 발사압력은 $1,350 \mathrm{psi}$ 로 하였다. 형질전환 후 안정화를 위해 24 시간 동안 $18^{\circ} \mathrm{C}, 5,000 \mathrm{LUX}$ 형 광등 빛에서 배양한 후, $100 \mu \mathrm{g} / \mathrm{mL}$ zeocin을 사용하여 형질전 환체를 선별하였다. 이 조건에서 음성대조군 형질전환체 4 개 콜 로니, 그리고 egfp 형질전환체 6개 콜로니를 얻을 수 있었다. 그러나 같은 조건에서 $P t h d r$ 유전자 형질전환체는 얻을 수가 없었다.

$P t h d r$ 유전자 형질전환체를 얻기 위해, 형질전환 시 두 가지 조건을 변경하여 실험을 진행하였다. 첫째로, gold microcarrier 에 코팅하는 플라스미드 양을 $1 \mu \mathrm{g}$ 부터 $4 \mu \mathrm{g}$ 까지 다르게 하였 다. 둘째는 bombardment후 P. tricornutum의 회복시간을 1일에 서 3일까지 변화하였다. P. tricornutum의 배가시간(doubling time)은 약 1 일이므로 회복시간을 길게 주면 형질전환 효율이 증가할 것으로 판단하였다(Martino 등, 2007). 그 결과 총 12 개 의 Pthdr 형질전환체 콜로니를 확보할 수 있었으며, 플라스미드 농도 2-3 $\mu \mathrm{g}, 2-3$ 일의 회복시간 조건에서 가장 많은 형질전환 효율을 얻을 수 있었다. 이를 통해 도입하는 유전자의 종류 및 크기에 따라 microcarrier에 코팅하는 플라스미드의 양 및 bombardment 후 치유시간의 차이가 형질전환 효율에 영향을 준 다는 것을 알 수 있었다.

선별배지 위에 형성된 각각의 콜로니를 $\mathrm{f} / 2$ 배지에서 $200 \mu \mathrm{L}$, $2.0 \mathrm{~mL}, 20 \mathrm{~mL}$, 그리고 $200 \mathrm{~mL}$ 순으로 부피를 늘리면서 배양 하였다. $200 \mu \mathrm{L}$ 부터 $20 \mathrm{~mL}$ 까지는 교반 배양하였고, $200 \mathrm{~mL}$ 에 서는 교반과 동시에 통기를 하였다. Pthdr 형질전환체의 경우, 콜로니로부터의 배양 도중에 2개 콜로니가 항생제 선별 과정에 서 자라지 못하였다.

Genomic DNA-PCR을 통한 유전자 삽입 확인. 본 실험에서 $P$.
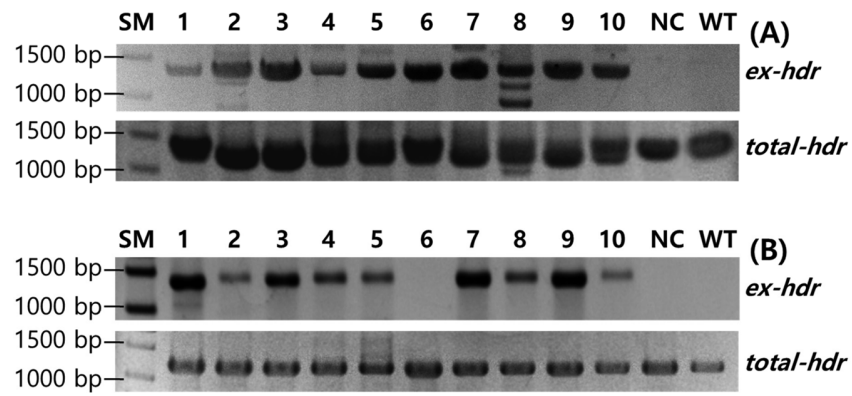

Fig. 4 Genomic DNA-PCR (A) and cDNA-PCR (B) of Pt-HDR mutants. Ex-hdr; exogenous $h d r$ (primers; PtHDR-F and pPha-T1-R), total- $h d r$; endogenous and exogenous $h d r$ (primers; PtHDR-F and PtHDR-R), SM; size marker, WT; wild type, NC; negative control (Pt-Blank), and 1-6; PtHDR mutants.

tricornutum에 형질전환시킨 세 종의 플라스미드가 크로모좀에 안정적으로 도입되었는지를 확인하기 위해서 genomic DNA$\mathrm{PCR}$ 을 수행하였다. 배양된 각 형질전환체로부터 genomic DNA 를 추출한 후 크로모좀에 도입된 플라스미드 $\mathrm{DNA}$ 를 검출할 수 있는 PCR을 수행하였다. DiatomCyc database에서 확인한 바에 의하면 Pthdr 유전자의 경우 $217 \mathrm{bps}$ 의 intron을 지니고 있을 것으로 추측되어 PCR을 통해 endogenous Pthdr 유전자와 플라 스미드 유래 Pthdr 유전자를 구별할 수 있을 것으로 기대하였 으나, PCR 결과 이의 구별이 명확하지 않았다. 이에 PCR시 자 가 유전자의 증폭을 제한하고 도입 유전자만 확인하기 위해, Pthdr 유전자 ORF 5' 말단 부분(PtHDR-F)과, pPha-T1 vector 의 multi cloning 지역(pPha-T1-R)을 기준으로 프라이머를 제작 하여 PCR을 진행하였다(Table 1). 그 결과 야생형(WT) 및 음 성 대조군(NC)을 제외한 Pthdr 형질전환체에서만 PCR 밴드를 확인할 수 있었다(Fig. 4). 이를 통해 pPha-T1-HDR 플라스미드 가 안정적으로 P. tricornutum의 크로모좀에 삽입되었음을 확인 할 수 있었다. 양성대조군인 6개의 egfp 형질전환체와 음성대조 군에서도 genomic DNA로부터 PCR을 통해 정확한 PCR 밴드 를 확인하여 $\mathrm{pPha}-\mathrm{T} 1-\mathrm{eGFP}$ 플라스미드가 안정적으로 도입되었 음을 확인할 수 있었다(Fig. 5).

유전자 발현 확인. 도입된 각각의 플라스미드가 정상적으로 목 적 유전자의 전사체를 만드는지 확인하기 위하여 cDNA-PCR을 통해 전사체를 확인하였다. pPha-T1 벡터는 목적 유전자의 발 현을 위해 미세조류 유래 $f c p A$ 프로모터를 사용하여 항상 안정 적인 전사체를 만들도록 디자인되었다(Zaslavskaia 등, 2000). $P t h d r$ 형질전환체의 경우, genomic DNA-PCR과 마찬가지로, 자 가 유전자 증폭을 제한하기 위해 PtHDR-F/pPha-T1-R 프라이머 조합을 사용하여 $\mathrm{PCR}$ 을 수행한 결과, Fig. 4에 나타낸 것처럼 각 형질전환체의 전사체 발현이 다양한 정도로 나타남을 확인 할 수 있었다. 하지만 6번 형질전환체는 Pthdr 유전자 증폭이 전혀 이루어지지 않았고, 10 번 형질전환체는 다른 형질전환체 에 비해 약한 발현량을 보였다. 야생형과 음성대조군에서는 플 라스미드 유래 Pthdr 유전자 증폭을 확인할 수 없었다. 이는 미 세조류의 형질전환에서 외래 유전자를 도입했을 경우 gene silencing 효과가 자주 나타난다는 보고가 있기 때문에 그러한 현상의 일부로 해석할 수 있을 것 같다(Cerutti 등, 2011). $P t h d r$ 자가 유전자의 전사체와 플라스미드 유래 전사체를 모두 포함하는 전체 Pthdr 유전자의 전사체 PCR 결과는 Fig. 4와 같다. 이 결과에서 모든 형질전환체 및 야생형, 음성대조군에서 


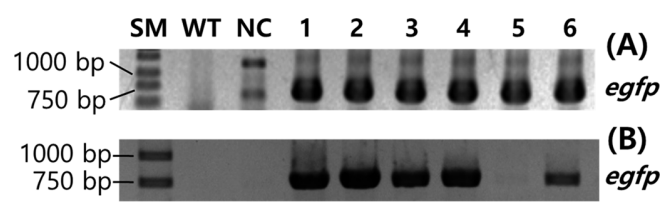

Fig. 5 Genomic DNA-PCR (A) and cDNA-PCR (B) of Pt-eGFP mutants (primers; eGFP-F and eGFP-R). SM; size marker, WT; wild type, NC; negative control (Pt-Blank), and 1-6; Pt-eGFP mutants.

모두 전사체가 증폭되는 것을 확인할 수 있었는데, 이는 자생 $P t h d r$ 유전자가 일반적으로 어느 정도 발현되고 있음을 알 수 있었다. 앞으로 $f c p A$ 프로모터 조절을 받는 도입된 $P t h d r$ 유전 자의 발현이 야생형 P. tricornutum의 MEP 대사경로 및 그 이 후의 카로티노이드 등의 생합성에 어떻게 영향을 주는지 추가 적인 연구가 필요하다. 한편 양성대조군인 egfp 형질전환체에서 는 5 번에서만 gene silencing 현상이 관찰되었고, 나머지 형질전 환체에서는 모두 $e g f p$ 전사체가 잘 발현이 된 것을 확인할 수 있었다(Fig. 5).

공초점 현미경을 통한 eGFP 단백질 발현 조사. pPha-T1-eGFP 플라스미드가 도입된 P. tricornutum 형질전환체 내에 발현된 $\mathrm{eGFP}$ 단백질은 형광 공초점 현미경을 통해 확인할 수 있었다 (Fig. 6). 각 형질전환체에서 eGFP 단백질의 발현은 이미 보고 된 결과와 마찬가지로 엽록체를 제외한 세포질(cytoplasm)에서 발현되는 것을 확인할 수 있었다(Tanaka 등, 2005). 이와 대조 적으로 P. tricornutum의 야생형과 음성대조군에서는 $\mathrm{eGFP}$ 의 발 현을 확인할 수 없었다. 이 결과를 바탕으로 $\mathrm{pPha-T1}$ 벡터를 활용한 형질전환체에서 도입 유전자가 단백질 수준까지 잘 작 동하고 있음을 확인할 수 있었다. 현 단계에서는 도입한 $P t h d r$ 유전자가 단백질 수준까지 잘 발현되는지를 확인할 수 없으나, egfp 형질전환체에서 단백질이 잘 발현되는 것이 확인된 만큼 도입된 Pthdr 유전자도 단백질까지 잘 발현된 것이라고 예상할
수 있었다. 단백질 발현량은 직접적으로 확인하지는 못하였으나, 이미 보고된 논문을 참고하면, P. tricornutum에서 $\mathrm{pPha}-\mathrm{T} 1$ vector를 사용한 형질전환 후, GFP발현량이 총 단백질량의 0.3 $\%$ 로 보고된 바 있다(Niu 등, 2012).

\section{초 록}

해양 미세조류인 Phaeodactylum tricornutum은 게놈 염기서열 이 완전히 밝혀진 규조류로서, 형질전환 방법이 개발되어 있고, 여러 가지 분자생물학적 연구 기술이 개발되어 규조류 연구에서 모델 종으로 여겨지고 있다. 본 연구의 목적은 methylerythritol phosphate (MEP) 대사경로의 마지막 효소인 (E)-4-hydroxy-3methylbut-2-enyl diphosphate reductase (HDR)를 코딩하는 $P$. tricornutum 의 Pthdr 유전자를 P. tricornutum에 도입하여 형질 전환체를 확보하는 것이다. 유전자 도입 방법은 gold microcarrier 를 사용한 bombardment 방법을 사용하였고, 형질전환 유무 및 목적 유전자의 전사체 확인에는 각각 genomic DNA-PCR 및 cDNA-PCR 방법을 사용하였다. 양성대조군으로 egfp 유전자를 P. tricornutum 에 도입하여 최종적으로 eGFP 단백질이 발현되 는 것을 형광 공초점 현미경을 통해 확인하였다. 이를 바탕으 로, 확보된 Pthdr 형질전환체에서도 도입한 $P t h d r$ 유전자로부터 발현된 PtHDR 효소도 잘 발현될 것으로 추측할 수 있었다. 이 렇게 준비된 Pthdr 형질전환체는 추후 연구를 통해, P. tricornum 의 유용물질인 카로티노이드의 생합성 과정 연구 및 고부가가 치 카로티노이드 과발현 균주 개발 등에 유용한 정보를 제공할 것으로 기대된다.

Keywords 형질전환 · bombardment · (E)-4-hydroxy-3methylbut-2-enyl diphosphate reductase $\cdot$ Phaeodactylum tricornutum
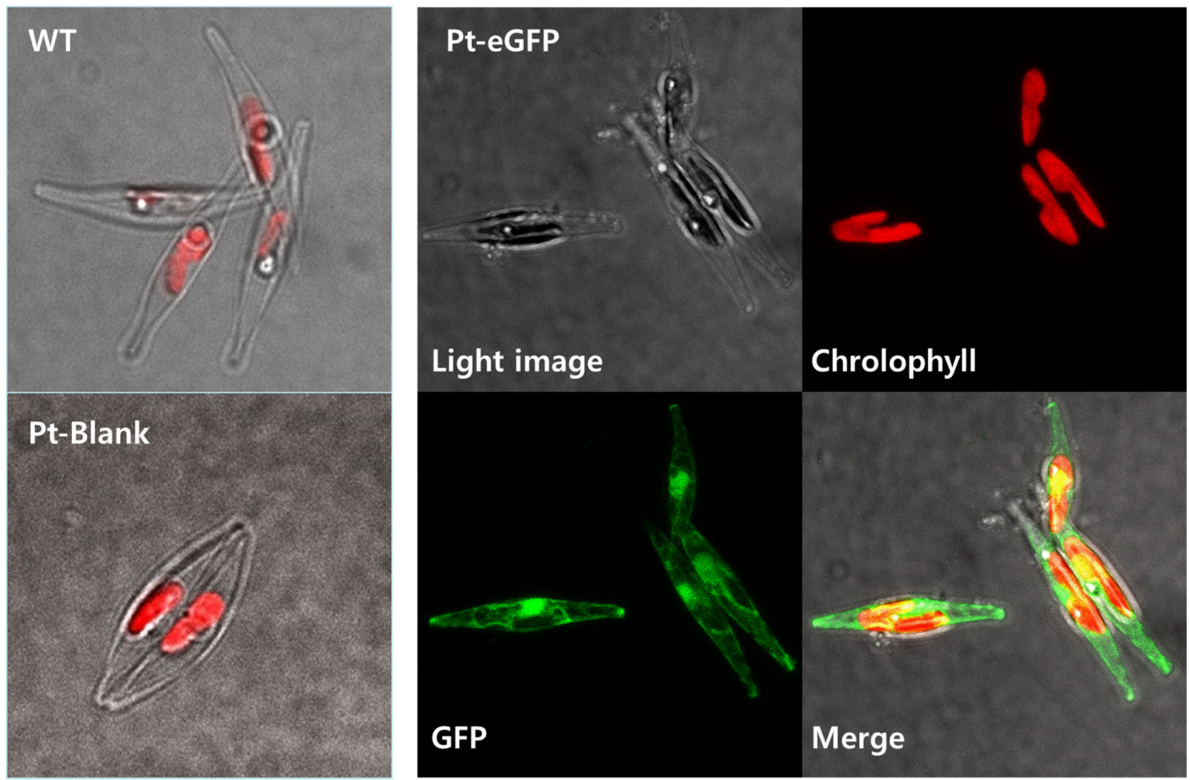

Fig. 6 Confocal images of Pt-eGFP mutants (excitation: $488 \mathrm{~nm}$, emission: $507 \mathrm{~nm}$ ). The eGFP protein was expressed in a cytosol of the Pt-eG transformant. WT: wild type, Pt-Blank; negative control, Chlorophyll; autofluorescence of chlorophyll, GFR; eGFP emission. 
감사의 글 이 논문은 2014년 해양수산부 재원으로 한국해양과학기술진흥 원의 지원을 받아 수행된 연구임(해양 미세조류로부터 고부가 향장 원료의 개발 및 산업화).

\section{References}

Altincicek B, Duin EC, Reichenberg A, Hedderich R, Kollas AK, Hintz M et al. (2002) LytB protein catalyzes the terminal step of the 2-C-methyl-Derythritol-4-phosphate pathway of isoprenoid biosynthesis. FEBS Lett 532, 437-40.

Apt KE, Grossman A, and Kroth-Pancic P (1996) Stable nuclear transformation of the diatomPhaeodactylum tricornutum. Mol Gene Genet 252, 572-9.

Borowitzka MA and Volcani BE (1978) The Polymorphic Diatom Phaeodactylum tricornutum: Ultrastructure of Its Morphotypes 1, 2. J Phycol 14, 10-21.

Bowler C, Allen AE, Badger JH, Grimwood J, Jabbari K, Kuo A et al. (2008) The Phaeodactylum genome reveals the evolutionary history of diatom genomes. Nature 456, 239-44.

Cerutti H, Ma X, Msanne J, and Repas T (2011) RNA-mediated silencing in algae: biological roles and tools for analysis of gene function. Eukaryot Cell 10, 1164-72.

De Riso V, Raniello R, Maumus F, Rogato A, Bowler C, and Falciatore A (2009) Gene silencing in the marine diatom Phaeodactylum tricornutum. Nucleic Acids Res 37, e96.

Falciatore A, Casotti R, Leblanc C, Abrescia C, and Bowler C (1999) Transformation of nonselectable reporter genes in marine diatoms. Mar Biotechnol 1, 239-51.

Falkowski PG, Barber RT, and Smetacek V (1998) Biogeochemical controls and feedbacks on ocean primary production. Science 281, 200-6.

Field CB, Behrenfeld MJ, Randerson JT, and Falkowski P (1998) Primary production of the biosphere: integrating terrestrial and oceanic components. Science 281, 237-40.

Francius G, Tesson B, Dague E, MartinJézéquel V, and Dufrêne YF (2008) Nanostructure and nanomechanics of live Phaeodactylum tricornutum morphotypes. Environ Microbiol 10, 1344-56.

Gräwert T, Kaiser J, Zepeck F, Laupitz R, Hecht S, Amslinger S et al. (2004) IspH protein of Escherichia coli: studies on iron-sulfur cluster implementation and catalysis. J Am Chem Soc 126, 12847-55.

Gräwert T, Rohdich F, Span I, Bacher A, Eisenreich W, Eppinger J et al. (2009) Structure of active IspH enzyme from Escherichia coli provides mechanistic insights into substrate reduction. Angew Chem Int Ed Engl 48, 5756-9.

Gräwert T, Span I, Eisenreich W, Rohdich F, Eppinger J, Bacher A et al (2010) Probing the reaction mechanism of $\mathrm{IspH}$ protein by X-ray structure analysis. Proc Natl Acad Sci U S A 107, 1077-81.

Guillard RL (1975) Culture of Phytoplankton for Feeding Marine Invertebrates In Culture of Marine Invertebrate Animals, Smith W and Chanley M (1 st ed.), pp. 29-60, Springer US., USA.

Guillard RRL and Ryther JH (1962) Studies of Marine Planktonic Diatoms: I. cyclotella Nana Hustent, and Detonula confervacea (Cleve) Gran. Can J Microbiol 8, 229-39.

He L, Han X, and Yu Z (2014) A rare Phaeodactylum tricornutum cruciform morphotype: culture conditions, transformation and unique fatty acid characteristics. PLoS One 9, e93922.

Kang MK, Nargis S, Kim SM, and Kim SU (2013) Distinct expression patterns of two Ginkgo biloba 1-hydroxy-2-methyl-2-(E)-butenyl-4diphosphate reductase/isopentenyl diphospahte synthase (HDR/IDS) promoters in Arabidopsis model. Plant Physiol Biochem 62, 47-53.

Kim SM, Kuzuyama T, Kobayashi A, Sando T, Chang YJ, and Kim SU (2008) 1-Hydroxy-2-methyl-2-(E)-butenyl 4-diphosphate reductase (IDS) is encoded by multicopy genes in gymnosperms Ginkgo biloba and Pinus taeda. Planta 227, 287-98.

Kroth P (2007) Molecular biology and the biotechnological potential of diatoms In Transgenic microalgae as green cell factories, León R, Galván A, and Fernández E (1 st ed.), pp. 23-33, Springer US., USA.

Lewin JC, Lewin R, and Philpott D (1958) Observations on Phaeodactylum tricornutum. J Gen Microbiol 18, 418-26.

Lohr M, Schwender J, and Polle JE (2012) Isoprenoid biosynthesis in eukaryotic phototrophs: a spotlight on algae. Plant Sci 185, 9-22.

Maeda H, Hosokawa M, Sashima T, Funayama K, and Miyashita K (2005) Fucoxanthin from edible seaweed, Undaria pinnatifida, shows antiobesity effect through UCP1 expression in white adipose tissues. Biochem Biophys Res Commun 332, 392-7.

Maheswari U, Mock T, Armbrust EV, and Bowler C (2009) Update of the Diatom EST Database: a new tool for digital transcriptomics. Nucleic Acids Res 37, D1001-D5.

Maheswari U, Montsant A, Goll J, Krishnasamy S, Rajyashri KR, Patell VM et al. (2005) The Diatom EST Database. Nucleic Acids Res 33, D344 D7.

Martino AD, Meichenin A, Shi J, Pan K, and Bowler C (2007) Genetic and phenotypic characterization of Phaeodactylum tricornutum (Bacillariophyceae) accessions1. J Phycol 43, 992-1009.

Matsumoto M, Hosokawa M, Matsukawa N, Hagio M, Shinoki A, Nishimukai $M$ et al. (2010) Suppressive effects of the marine carotenoids, fucoxanthin and fucoxanthinol on triglyceride absorption in lymph duct-cannulated rats. European journal of nutrition 49, 243-9.

Niu Y, Yang Z, Zhang M, Zhu C, Yang W, Liu J et al. (2012) Transformation of diatom Phaeodactylum tricornutum by electroporation and establishment of inducible selection marker. Biotechniques, 1-3.

Nomura T, Kikuchi M, Kubodera A, and Kawakami Y (1997) Protondonative antioxidant activity of fucoxanthin with 1, 1diphenyl2picrylhydrazyl (DPPH). IUBMB Life 42, 361-70.

Owens TG (1986) Light-harvesting function in the diatom Phaeodactylum tricornutum II. Distribution of excitation energy between the photosystems. Plant Physiol 80, 739-46.

Patil V (2005) Microalgae as a source of polyunsaturated fatty acids for aquaculture. Curr Topics Plant Biol 6, 57-65.

Rohdich F, Hecht S, Gärtner K, Adam P, Krieger C, Amslinger S et al. (2002) Studies on the nonmevalonate terpene biosynthetic pathway: metabolic role of IspH (LytB) protein. Proc Natl Acad Sci U S A 99, 1158-63.

Round FE, Crawford RM, and Mann DG (1990) In The diatoms: biology \& morphology of the genera, (2nd ed.) Cambridge University Press, UK.

Shin B-K, Ahn J-H, and Han J (2015) N-Terminal Region of GbIspH1, Ginkgo biloba IspH Type 1, May Be Involved in the pH-Dependent Regulation of Enzyme Activity. Bioinorganic chemistry and applications 2015, 1-8.

Siaut M, Heijde M, Mangogna M, Montsant A, Coesel S, Allen A et al. (2007) Molecular toolbox for studying diatom biology in Phaeodactylum tricornutum. Gene 406, 23-35.

Span I, Gräwert T, Bacher A, Eisenreich W, and Groll M (2012) Crystal structures of mutant IspH proteins reveal a rotation of the substrate's hydroxymethyl group during catalysis. $J$ Mol Biol 416, 1-9.

Talero E, Avila-Roman J, and Motilva V (2012) Chemoprevention with phytonutrients and microalgae products in chronic inflammation and colon cancer. Curr Pharm Des 18, 3939-65.

Tanaka Y, Nakatsuma D, Harada H, Ishida M, and Matsuda Y (2005) Localization of soluble $\beta$-carbonic anhydrase in the marine diatom Phaeodactylum tricornutum. Sorting to the chloroplast and cluster formation on the girdle lamellae. Plant Physiol 138, 207-17.

Werner D (1977) In The biology of diatoms. Univ of California Press, USA.

Wolff M, Seemann M, Tse Sum Bui B, Frapart Y, Tritsch D, Garcia Estrabot A et al. (2003) Isoprenoid biosynthesis via the methylerythritol phosphate pathway: the (E)-4-hydroxy-3-methylbut-2-enyl diphosphate reductase $(\mathrm{LytB} / \mathrm{IspH})$ from Escherichia coli is a $[4 \mathrm{Fe}-4 \mathrm{~S}]$ protein. FEBS Lett 541, 115-20.

Zaslavskaia LA, Lippmeier JC, Kroth PG, Grossman AR, and Apt KE (2000) Transformation of the diatom Phaeodactylum tricornutum (Bacillariophyceae) with a variety of selectable marker and reporter genes. J Phycol 36, 37986. 